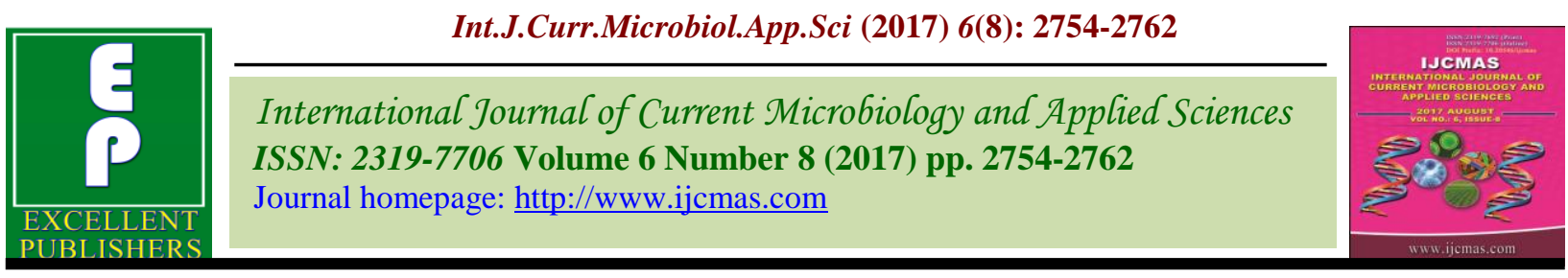

Original Research Article

https://doi.org/10.20546/ijcmas.2017.608.329

\title{
Evaluation of Fungicides, Bioagents and Plant Extracts against Exserohilum turcicum Causing Turcicum Leaf Blight of Maize
}

\author{
T.A. Wani ${ }^{1^{*}}$, Mushtaq Ahmad ${ }^{2}$ and A. Anwar ${ }^{3}$ \\ ${ }^{1}$ Department of Plant Pathology, FOA SKUAST-K Wadura Sopore, India \\ ${ }^{2}$ Directorate of Extension, SKUAST-K Shalimar Srinagar, India \\ ${ }^{3}$ Division of Plant Pathology, SKUAST-K Shalimar Srinagar, India \\ *Corresponding author
}

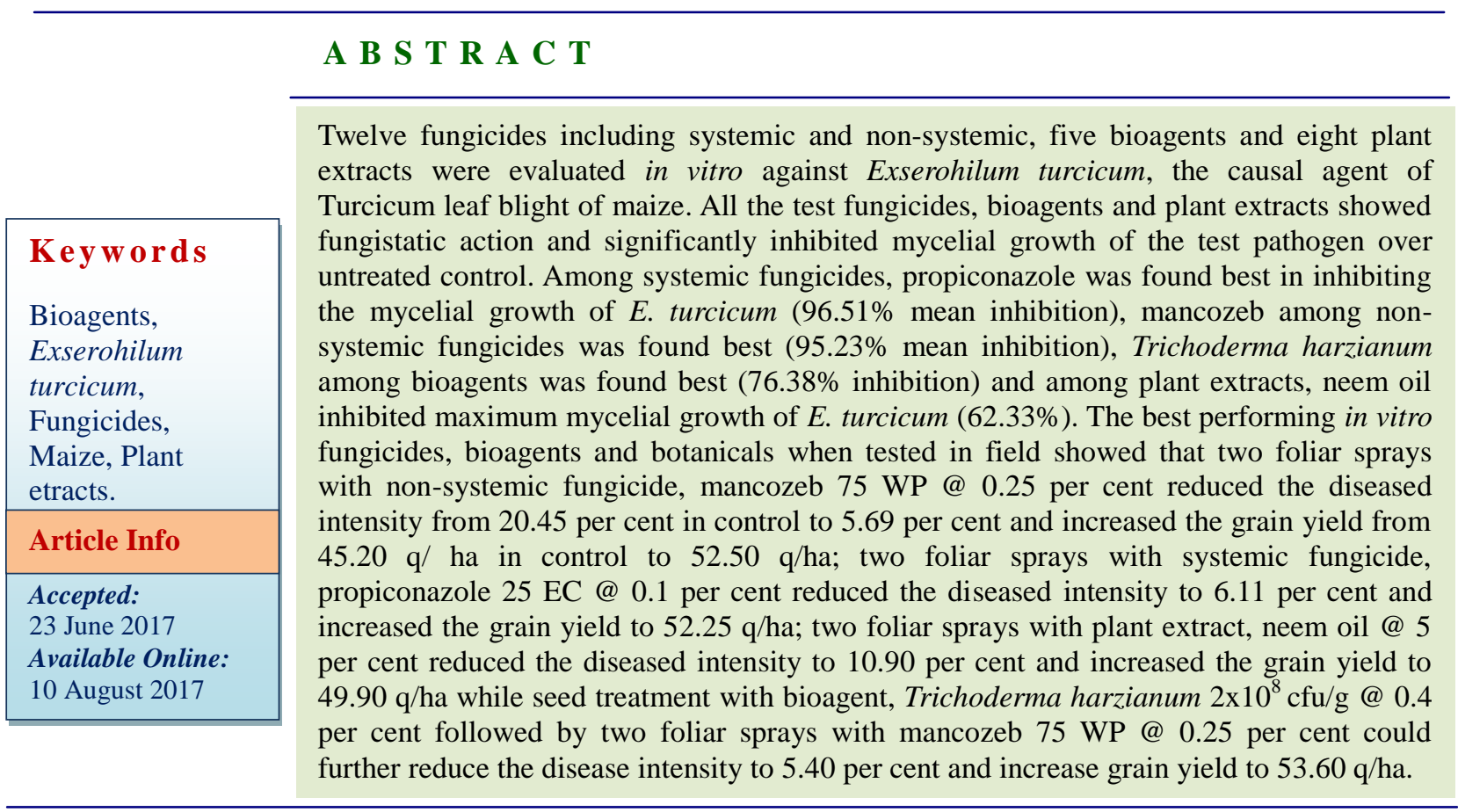

\section{Introduction}

Turcicum leaf blight of maize (Zea mays L.) caused by Exserohilum turcicum (Pass.) Leonard and Suggs, was first reported by Passerini in 1876 from Perma, Italy.

This disease is popularly known as Northern Corn Leaf Bight (NCLB) in the United States of America. The disease is favoured by mild temperature and high humidity (Ullstrup, 1970). Heavy dews, cool temperature and frequent rains are environmental conditions conducive for disease development (Jordan et al., 1983). In India the disease was first reported by Butler et al., (1920). Later the disease was reported from Kashmir (Koul, 1957) and Himachal Pradesh (Chenula and Hora, 1962). The disease is considered to be one of the most devastating diseases as its occurrence and incidence assumes greater significance resulting in reduction of grain yield by 28 to 91 per cent (Kachapur, 1998 and Harlapur et al., 2000). Hence an attempt 
was made to evaluate various fungicides, bioagents and plant extracts in vitro and in vivo to manage the disease.

\section{Materials and Methods}

\section{Isolation of the pathogen}

The fungus was isolated by tissue isolation technique. The diseased tissues along with some healthy leaf portion (1-2 $\left.\mathrm{mm}^{2}\right)$ were cut with a sterilized razor blade at the margins of the diseased spots and surface sterilized in 0.1 per cent mercuric chloride solution for 30 seconds. The segments were then rinsed thrice in sterilized distilled water to remove the traces of mercuric chloride solution, blotted dry and placed on acidified potato dextrose agar (PDA) medium ( $\mathrm{pH}$ adjusted to 6.5 with $\mathrm{N} / 10 \mathrm{HCl}$ ) in sterilized petriplates under aseptic conditions. The inoculated PDA plates were incubated at $25 \pm 1{ }^{\circ} \mathrm{C}$ for 7 days and sub cultured onto fresh PDA medium at the same temperature for 15 days.

\section{Purification by single spore technique}

Exserohilum turcicum being a sporulating fungus was purified by single spore technique (Johnston and Booth, 1983). Dilute spore suspension of the pathogen was prepared in sterilized distilled water containing 8 to 10 spores per microscopic field at low power from 15 days old culture.

One $\mathrm{ml}$ of such suspension was spread uniformly on 2 per cent solidified water agar plates and incubated at $25 \pm 1^{\circ} \mathrm{C}$ for 12 hours. The plates were examined under stereoscopic microscope, single spores were marked with a marker, allowed to germinate and finally picked up using cork borer and transferred aseptically to potato dextrose agar medium in sterilized petriplates for further growth in the incubator at $25 \pm 1^{\circ} \mathrm{C}$. The pure culture thus obtained, was used for further studies.

\section{In vitro evaluation of fungicides}

Twelve fungicides consisting of six systemic viz., carbendazim 50 WP (Bavistin), propiconazole $25 \mathrm{EC}$ (Tilt), difenconazole 25 EC (Score), tridemorph 75 EC (Calaxin), thiophanate methyl 70 WP (Topsin-M) and hexaconazole 5 EC (Anvil); four nonsystemic viz., mancozeb 75 WP (Indofil M 45), copper oxychloride 50 WP (Connect), captan $50 \mathrm{WP}$ (Merimain) and chlorothalonil 75 WP (Kavach) and two combi-products viz., captan 70 per cent + hexaconazole 5 per cent (Taqat $75 \mathrm{WP}$ ) and carbendazim 12 per cent + mancozeb 63 Per cent (Saaf 75 WP) were assayed for their efficacy against $E$. turcicum under in vitro condition. The systemic fungicides were tested at 100, 250 and $500 \mathrm{ppm}$ concentrations, non-systemic fungicides were tested at 500, 1000 and 1500 ppm concentrations, whereas, one combiproduct, carbendazim 12 per cent + mancozeb 63 per cent (Saaf 75 WP) was tested at same concentration as of non-systemic fungicides, i.e., 500, 1000 and 1500 ppm, while as other combi-product, captan $70 \%+$ hexaconazole $5 \%$ (Taqat $75 \mathrm{WP}$ ) was tested at same concentration as used for systemic fungicides, i.e., 100, 250 and 500 ppm. Poisoned food technique was adopted for in vitro testing of fungicides (Nene and Thapliyal, 1979). The calculated amount of fungicides were thoroughly mixed in the medium before pouring into petriplates so as to get desired concentration of active ingredient of each fungicide separately. Twenty $\mathrm{ml}$ of fungicide amended medium was poured in each of 90 $\mathrm{mm}$ sterilized petriplates and allowed to solidify. The plates were inoculated centrally with $5 \mathrm{~mm}$ disc of ten days old young sporulating culture of Exserohilum turcicum. Control plates without fungicides were also maintained. The experiment was conducted in completely randomized design (CRD) with three replications in each treatment. The inoculated petriplates were incubated at 
$25 \pm 1^{\circ} \mathrm{C}$ in the laboratory. The colony diameters were measured when the fungus touched the periphery in control plates. Per cent inhibition of growth was calculated by using formula given by Vincent (1927) as:

$\mathrm{I}=\frac{C-T}{C} \times 100$

Where,

$\mathrm{I}=$ Per cent Inhibition

$\mathrm{C}=$ Colony diameter in control;

$\mathrm{T}=$ Colony diameter in treatment

\section{In vitro evaluation of bioagents}

The fungal bio-control agents, viz., Trichoderma viride Pers., Trichoderma harzianum Rifai, Aspergillus niger Van Tiegh, Pseudomonas fluorescens (Trevisan) Migula and Bacillus subtilis (Ehrenberg) Cohn, were evaluated against Exserohilum turcicum for their antagonistic activity by using dual culture method as described below. Culture discs $(5 \mathrm{~mm})$ of each fungal antagonist and the pathogen were taken from the margin of the actively growing cultures and transferred to potato dextrose agar (PDA) medium contained in $90 \mathrm{~mm}$ petriplates on opposite side, approximately at $10 \mathrm{~mm}$ from the wall of the plate. Similarly, bacteria were streaked on the opposite side of the pathogen.

A check having the test pathogen only was kept for comparison. The experiment was conducted in completely randomized design (CRD) with three replications in each treatment. The petriplates were subsequently incubated at $25 \pm 1^{\circ} \mathrm{C}$ till mycelial inhibition was observed. Colony diameter of the test fungus as well as each antagonist up to the zone of inhibition was recorded as the per cent growth inhibition of the test pathogen over control, calculated according to the formula given by Vincent (1927).

\section{In vitro evaluation of plant extracts}

Eight plant extracts, viz., onion clove, garlic bulb, mint leaf, datura leaf, datura seed, datura root, artimesia leaf and neem oil were tested against the growth of Turcicum leaf blight of maize pathogen, E. turcicum under in vitro conditions by poisoned food technique (Nene and Thapliyal, 1979). The fresh leaves and other parts of healthy plants were collected and washed with sterile distilled water and air dried. Ten grams of plant tissue was ground using pestle and mortar by adding equal amount $(10 \mathrm{ml})$ of sterilized distilled water $(1: 1 \mathrm{w} / \mathrm{v})$. The extract was filtered through muslin cloth and centrifuged at $2000 \mathrm{rpm}$ for 30 minutes at ambient temperature $\left(26 \pm 2^{\circ} \mathrm{C}\right)$. This supernatant was used as standard plant extract solution $(100 \%)$. The plant extracts were tested at 10 per cent concentration and besides plant extracts, commercial neem formulation, Nimbicidin (neem oil) was tested at 5 per cent concentration and this was achieved by incorporating $10 \mathrm{ml}$ supernatant of each plant extract and $5 \mathrm{ml}$ of Nimbicidin into $90 \mathrm{ml}$ and $95 \mathrm{ml}$ of PDA media in conical flasks, respectively, and such conical flasks [containing PDA (food) and plant extract (poison) known as poisoned food technique] were sterilized by autoclaving at 15 psi for 20 minutes (Sood and Dohroo, 2003; Verma and Dohroo, 2003; Dutta and Kahla, 2011).

Twenty $\mathrm{ml}$ of PDA containing plant extract was poured into sterilized petriplate under aseptic conditions (in laminar air flow) and allowed to solidify. PDA plates containing the plant extracts were inoculated aseptically in the center with $5 \mathrm{~mm}$ disc of ten days old young sporulating culture of Exserohilum turcicum. Control plates without any plant extracts were also maintained. The experiment was conducted in completely randomized design (CRD) with three replications in each treatment. The inoculated 
petriplates were incubated at $25 \pm 1^{\circ} \mathrm{C}$ in the laboratory. The colony diameters were measured when the fungus touched the periphery in control plates. Per cent inhibition of growth was calculated by using formula given by Vincent (1927).

\section{In vivo evaluation of fungicides, bioagents and plant extracts}

Field experiments were conducted during kharif 2012 and 2013 at Sher-e-Kashmir University of Agricultural Sciences and Technology of Kashmir, Shalimar campus Srinagar to manage the disease using the best performing fungicides (mancozeb and propiconazole), bioagent (Trichoderma harzianum) and plant extract (neem oil) identified in vitro, which were integrated under field conditions as seed treatment and foliar sprays. The experiment was laid in randomized block design using Turcicum leaf blight susceptible variety of maize (C 15) and cultivated as per recommended package of practice. Artificial epiphytotic conditions were created twice at 25 and 30 DAS with two different methods of inoculation, first with spore suspension having spore load of 5 $\mathrm{x} 10^{4}$ spores per $\mathrm{ml}$ sprayed with atomizer on foliage of maize and second with whorl drop method inoculation of plants done with E.turcicum multiplied on Sorghum grains. The inoculations were done in the evening time and light water was sprayed after both inoculations to create high relative humidity for infection. The disease intensity was recorded at silk drying stage using 1-5 disease rating scale (James, 1971). The data on yield was recorded and analyzed statistically.

\section{Results and Discussion}

\section{Evaluation of fungicides}

Among the systemic fungicides, under in vitro conditions, the maximum inhibition of mycelial growth $(100 \%)$ was observed with propiconazole, followed by difenconazole $(84.75 \%)$ and the least inhibition was noticed with thiophanate methyl $(70.35 \%)$ at $500 \mathrm{ppm}$ concentration (Table 1). At 250 and $100 \mathrm{ppm}$ concentrations, similar trend was noticed. Further when the same fungicide, propiconazole $25 \mathrm{EC}$ at $0.1 \%$ was assessed under field conditions against Turcicum leaf blight of maize as two foliar sprays at 40 and 50 DAS, the disease intensity was reduced from 20.45 per cent recorded in control to 6.11 per cent and grain yield was increased from $45.20 \mathrm{q} / \mathrm{ha}$ recorded in control to 52.25 $\mathrm{q} / \mathrm{ha}$. These results are in agreement with Bowen and Pederson (1988) who studied the effect of propiconazole on E. turcicum in laboratory and field and found that three sprays of propiconazole at weekly intervals was effective in reducing Turcicum leaf blight in maize.

Among non-systemic fungicides, under in vitro conditions, the maximum inhibition of mycelial growth $(100 \%)$ was observed with mancozeb and least inhibition was recorded with captan (35.15\%) at $1500 \mathrm{ppm}$ concentration (Table 2). The combi-product, mancozeb + carbendazim also showed maximum inhibition (100\%) at $1500 \mathrm{ppm}$ while at lower concentrations, i.e., 1000 and $500 \mathrm{ppm}$, it was not as effective as mancozeb alone. Further mancozeb $75 \mathrm{WP}$ at $0.25 \%$ was assessed under field conditions against Turcicum leaf blight of maize as two foliar sprays at 40 and $50 \mathrm{DAS}$, the disease intensity was reduced from 20.45 per cent recorded in control to 5.69 per cent and grain yield was increased from $45.20 \mathrm{q} / \mathrm{ha}$ recorded in control to $52.50 \mathrm{q} / \mathrm{ha}$. These results are in agreement with Kumar et al., (1977) who evaluated eight fungicides and found that mancozeb, Unizeb and Dithane Z-78 significantly reduced the maize leaf blight severity by $55,47.4$ and 44.33 per cent, respectively and increased the grain yield by $8.54,10.12$ and 9.9 per cent, 
respectively. Other investigations also indicated that mancozeb was most effective in controlling Turcicum leaf blight of maize (Pandurangegowda, 1987 and Begum et al., 1993). Reddy et al., (2013) evaluated seven fungicides in vitro against $E$. turcicum causing leaf blight of maize and found treatment mancozeb@0.25 per cent and combination treatment of mancozeb and carbendazim, i.e., Saff @ 0.25 per cent recorded the lowest per cent disease index (PDI) reducing the disease by 73.0 and 72.1 per cent, respectively

Table.1 In vitro efficacy of various systemic fungicides in inhibiting the mycelial growth of Exserohilum turcicum

\begin{tabular}{|c|c|c|c|c|}
\hline \multirow{2}{*}{ Fungicide } & \multicolumn{2}{|c|}{ Per cent growth inhibition at different concentrations (ppm) } \\
\cline { 2 - 5 } & $\mathbf{C}_{\mathbf{1}}$ & $\mathbf{C}_{\mathbf{2}}$ & $\mathbf{C}_{\mathbf{3}}$ & \multirow{2}{*}{ Mean } \\
\cline { 2 - 5 } & $\mathbf{1 0 0}$ & $\mathbf{2 5 0}$ & $\mathbf{5 0 0}$ & \\
\hline Carbendazim 50 WP & $33.25(35.21)$ & $57.47(49.29)$ & $78.24(62.16)$ & $56.32(48.63)$ \\
\hline Propiconazole 25 EC & $90.27(71.82)$ & $99.26(85.06)$ & $100.00(90.00)$ & $96.51(79.23)$ \\
\hline Difenconazole 25 EC & $56.74(48.87)$ & $70.62(57.17)$ & $84.75(67.01)$ & $70.70(57.22)$ \\
\hline Tridemorph 75 EC & $55.71(48.27)$ & $68.54(55.88)$ & $82.61(65.35)$ & $68.95(56.13)$ \\
\hline Thiophenate methyl 70 WP & $43.30(41.14)$ & $56.27(48.60)$ & $70.35(57.00)$ & $56.64(48.81)$ \\
\hline Hexaconazole 5 EC & $53.51(47.01)$ & $66.47(54.61)$ & $80.67(63.91)$ & $66.88(54.86)$ \\
\hline Captan (70\%) + Hexaconazole (5\%) & $54.51(47.58)$ & $67.34(55.14)$ & $81.33(54.41)$ & $67.73(55.37)$ \\
\hline Mean & $55.32(48.04)$ & $69.42(56.42)$ & $82.56(65.31)$ & \\
\hline
\end{tabular}

Figures in the parenthesis are arc sine transformed values

$\begin{array}{lll}\mathrm{CD}_{(\mathrm{p} \leq 0.05)} & : & 0.26 \\ \text { Fungicide } & : & 0.17 \\ \text { Concentration } & : & 0.45\end{array}$

Table.2 In vitro efficacy of various non-systemic fungicides in inhibiting the mycelial growth Exserohilum turcicum

\begin{tabular}{|c|c|c|c|c|}
\hline \multirow{2}{*}{ Fungicide } & \multicolumn{3}{|c|}{ Per cent growth inhibition at different concentrations (ppm) } \\
\cline { 2 - 4 } & $\mathbf{C}_{\mathbf{1}}$ & $\mathbf{C}_{\mathbf{2}}$ & $\mathbf{C}_{\mathbf{3}}$ & \multirow{2}{*}{ Mean } \\
\cline { 2 - 4 } & $\mathbf{5 0 0}$ & $\mathbf{1 0 0 0}$ & $\mathbf{1 5 0 0}$ & \\
\hline Mancozeb 75 WP & $89.12(70.74)$ & $96.57(79.32)$ & $100.00(90.00)$ & $95.23(77.38)$ \\
\hline Copper oxychloride 50 WP & $41.94(40.36)$ & $45.44(42.38)$ & $51.75(46.00)$ & $46.36(42.91)$ \\
\hline Captan 50 WP & $29.61(32.96)$ & $33.67(35.46)$ & $35.15(36.36)$ & $32.81(34.94)$ \\
\hline Chlorothalonil 50 WP & $61.80(51.82)$ & $66.22(54.46)$ & $71.74(57.88)$ & $66.58(54.68)$ \\
\hline Mancozeb (63\%) + Carbendazim (12\%) & $88.16(69.87)$ & $95.53(77.79)$ & $100.00(90.00)$ & $94.56(76.51)$ \\
\hline Mean & $62.12(52.01)$ & $67.48(55.23)$ & $71.72(57.87)$ & \\
\hline
\end{tabular}

-Figures in the parenthesis are arc sine transformed values

$\begin{array}{lll}\mathrm{CD}_{(\mathrm{p} \leq 0.05)} & : & 0.26 \\ \text { Fungicide } & : & 0.20 \\ \text { Concentration } & : & 0.46\end{array}$

Table.3 In vitro efficacy of various bio-agents on mycelial growth inhibition of Exserohilum turcicum

\begin{tabular}{|c|c|c|}
\hline S. No. & Bio-agent & Per cent inhibition in mycelial growth \\
\hline 1. & Trichoderma viride Pers (Fr.) & $62.61(52.31)$ \\
\hline 2. & Trichoderma harzianum Rifai & $76.38(60.92)$ \\
\hline 3. & Aspergillus niger Van Teigh & $42.52(40.70)$ \\
\hline 4. & Pseudomonos fluorescens Migula & $37.95(38.03)$ \\
\hline 5. & Bacillus subtilis (Ehrenberg) Cohn & $46.41(42.94)$ \\
\hline & S.Em \pm & 0.23 \\
\hline & CD $(\mathrm{p} \leq 0.05)$ & 0.95 \\
\hline
\end{tabular}

-Figures in parenthesis indicate arc sine values 
Table.4 In vitro efficacy of various plant extracts on mycelial growth inhibition of Exserohilum turcicum

\begin{tabular}{|c|c|c|c|c|}
\hline S. No. & Plant species & Part used & Conc. (\%) & Per cent inhibition of mycelial growth \\
\hline 1. & Allium cepa L. & Bulb & 10 & $25.33(30.21)$ \\
\hline 2. & Allium sativum L. & Clove & 10 & $36.67(37.26)$ \\
\hline 3. & Mentha spicata & Leaf & 10 & $20.00(26.56)$ \\
\hline 4. & Datura stramonium & Leaf & 10 & $41.33(40.00)$ \\
\hline 5. & Datura stramonium & Seed & 10 & $23.67(29.11)$ \\
\hline 6. & Datura stramonium & Root & 10 & $22.33(28.19)$ \\
\hline 7. & Artimesia annua & Leaf & 10 & $40.00(39.23)$ \\
\hline 8. & Azadirachta indica & Oil & 5 & $62.33(52.13)$ \\
\hline \multicolumn{2}{|c|}{ S.E \pm CD $\leq 0.05)$} & 0.07 \\
\hline
\end{tabular}

-Figures in parenthesis indicate arc sine values

Plate.1 In vitro evaluation of T. harzianum against Exserohilum turcicum by dual culture

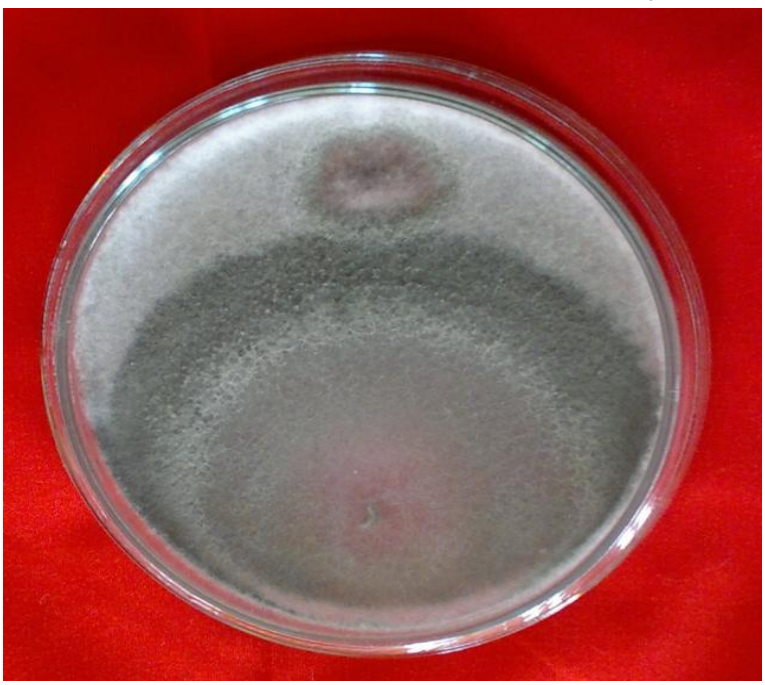

Trichoderma harzianum inhibiting Exserohilum turcicum

\section{Evaluation of bioagents}

It is apparent from the data presented in table 3 that all the antagonistic fungi and bacteria inhibited the growth of E. turcicum ranging from 37.95 to 76.38 per cent. T. harzianum was found to be superior over all treatments with 76.38 per cent mycelial inhibition (Plate1) followed by $T$. viride $(62.61 \%)$, B. subtilis (46.41\%) and $A$. niger (42.52) while $P$. fluorescens was found to be least effective $(37.95 \%)$. Further when most effective in vitro bioagent, $T$. harzianum was assessed and integrated with best in vitro fungicide under field conditions against Turcicum leaf blight

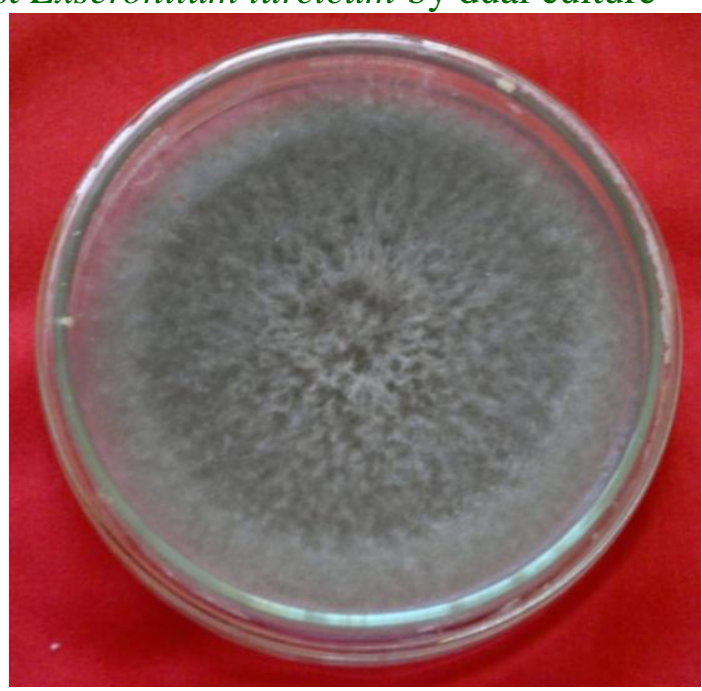

Control (Exserhilum turcicum)

of maize as seed treatment with $T$. harzianum $2 \times 10^{8} \mathrm{cfu} / \mathrm{g} @ 0.4$ per cent and two foliar sprays with mancozeb 75 WP @ 0.25 per cent the disease intensity was further reduced to 5.40 per cent and grain yield was further increased to $53.60 \mathrm{q} / \mathrm{ha}$. The antagonism of $T$. harzianum and $T$. viride observed in the present studies are in tune with the findings of various workers (Biles and Hill, 1988; Mehmood et al., 1995). Harlapur et al., (2007) reported that maximum mean per cent inhibition of mycelial growth of E. turcicum was recorded in $T$. harzianum $(65.17 \%)$ followed by $T$. viride (56.95\%).

Evaluation of plant extracts 
The data on effect of plant extracts on the growth of E. turcicum are presented in table 4 . The data revealed that significant reduction in the mycelial growth of E. turcicum was observed in respect of all the plant extracts tested. Among these, neem (Azadirachta indica) oil @5 per cent concentration caused maximum inhibition of mycelial growth $(62.33 \%)$ followed by leaf extract of Datura stramonium @ 10 per cent (41.33\%), leaf extract of Artimisia annulla @ 10 per cent $(40.0 \%)$, clove extract of garlic (Allium sativum)@10 per cent (36.67\%), bulb extract of onion (Allium cepa) @10 per cent $(25.33 \%)$ and seed extract of Datura stromonium @10 per cent (23.67\%), while leaf extract of mint (Mentha spicata) @ 10 per cent and root extract of Datura stramonium @ 10 per cent were least effective $(20.0 \%$ and $22.33 \%$ inhibition, respectively). Further when the most effective plant extract, i.e., neem oil (Nimbicibin) @ 5 per cent was assessed under field conditions against Turcicum leaf blight of maize as two foliar sprays at 40 and $50 \mathrm{DAS}$, the disease intensity was reduced from 20.45 per cent recorded in control to 10.90 per cent and grain yield was increased from $45.20 \mathrm{q} / \mathrm{ha}$ recorded in control to $49.90 \mathrm{q} / \mathrm{ha}$. Similar results on antifungal activity of aqueous extracts of different plants has been reported by various workers (Shivapuri et al., 1997; Singh et al., 1998; Meena et al., 2003). Harlapur et al., (2007) reported that, neem seed kernal extract (NSKE)@ 5 per cent was highly effective with significantly maximum inhibition of the pathogen, onion bulb extract was also fairly effective in inhibiting the growth of $E$. turcicum. The inhibitory action of NSKE may be due to azadirchitin present in seed kernel which retards the growth and activation of the pathogen. The effectiveness of onion bulb extract may be due to the presence of antifungal compounds such as cycloallin and carbohydrate propenyl sulphuric acid.
Khedkar et al., (2012) studied the efficacy of phyto extract on E. turcicum by poisoned food technique under in vitro conditions and found that Nimbicidin@5 per cent concentration was superior to all other treatments with the maximum mycelial inhibition of 68.85 per cent followed by negunda (38.88\%) and neem seed kernel extract $(37.01 \%)$.

\section{References}

Begum, H., Raj, R.B. and Satyanarayana, E. 1993. Field evaluation of five fungicides to control Turcicum leaf blight in maize. Indian Journal of Plant Protection 21: 110-111.

Biles, C.L. and Hill, J.P. 1988. Effect of Trichoderma harzianum on sporulation of Cochliobolus sativus on excised wheat seedling leaves. Phytopathology 78: 656-659.

Bowen, K.L. and Pederson, W.L. 1988. Effect of propiconazole on Exserohilum turcicum in laboratory and field studies. Plant Disease 72: 847-850.

Butler, E.J., Shaw J. F. and Mitra, A. K. 1920. Reports of imperial mycologist. Reports of Agricultural Research Institute and Collage, Pusa, New Delhi (cf: Indian Journal of Plant Genetic Resource 24(2): 343-345).

Chenula, V.V. and Hora, T.S. 1962. Studies on losses due to Helminthosporium blight of maize. Indian Phytopathology 15: 235-237.

Dutta, U., and Kalha, C.S. 2011. In vitro evaluation of fungicides, botanicals and bioagents against Rhizoctonia solani causing sheath blight of rice and their integration for effective management of the disease under field conditions. Plant Disease Research 26(1): 14-19.

Harlapur, S.I., Wali, M.C., Anahosur, K.H. and Muralikrishna, S. 2000. A report on survey and surveillance of maize diseases in northern Karnataka. 
Karnataka Journal of Agricultural Sciences 13: 750-751

Harlapur, S.I., Kulkarni, M.S., Wali, M.C. and Kulkarni, S. 2007. Evaluation of plant extracts, bio-agents and fungicides against Exserohilum turcicum (Pass.) Leonard and Suggs. Causing turcicum leaf blight of maize Karnataka Journal of Agricultural Sciences 20(3): 541-544.

James, W.C. 1971. An illustrated series of assessment keys for plant diseases, their preparation and usage. Canadian Plant Disease Survey 51: 39-65

Johnston, A. and Booth, C. 1983. Plant Pathologists Pocket Book. Commonwealth Mycological Institute, Kew, Surrey, England, pp. 439.

Jordan, E.G., Perkins, J.M., Schall, R.A. and Pederson, W.L. 1983. Occurrence of race 2 of Exserohilum turcicum on corn in central United States. Plant Disease 67: 1163-1165.

Kachapur, M.R., and Hegde, R.K. 1988. Studies on Turcicum leaf blight caused by Exserohilum turcicum with special reference to crop loss assessment. Plant Pathology Newsletter 6: 33-35 (cf: Karnataka Journal of Agricultural Sciences 20(3): 665-666).

Khedekar, S.A., Harlapur, S.I., Kulkarni, S. and Benagi, V.I. 2012. Evaluation of fungicides, botanicals and bioagents against Turcicum leaf blight of maize caused by Exserohilum turcicum (Pass.) Leonard and Suggs. International Journal of Plant Protection 5 (1): 5862.

Koul, T.N. 1957. Out breaks and new records. Food and Agriculture Organization. Plant Protection Bulletin 5(6): 93-96.

Kumar, S.U., Gupta, K. and Mahammad, M. 1977. Studies on leaf blight of maize caused by Helminthosporium turcicum and $H$. maydis. Science and Culture 42: 533-535.

Mahmood, A., Javed, N., Ahmad, R. and
Raheel, Z.I. 1995. Biological control of maize leaf blight caused by Helminthosporium turcicum Pass. In vitro. Pakistan Journal of Phytopathology 7: 62-64.

Meena, R.L., Rathore, R.S. and Mathur, K. 2003. Evaluation of fungicides and plant extracts against banded leaf and sheath blight of maize. Indian Journal of Plant Protection 31: 94-97.

Nene, Y.L. and Thapliyal, P.N. 1979. Fungicides in Plant Disease Control. Oxford and IBH Publishing House, New Delhi, pp 525-540.

Pandurangegowda, K.T., 1987, Status of breeding and management of Turcicum leaf blight of maize. Progressive Report, $30^{\text {th }}$ Annual Maize Workshop, April 1720, AICMIP, IARI, New Delhi, pp. 2128.

Passerini, 1876. Lanebbia Delgranotur Co. Bol. Comiz, Agriculture. Parmense 10: 3. (cf: Karnataka Journal of Agricultural Sciences 20 (3): 655-666).

Reddy, T. R., Reddy, N.P., Reddy, R.R. and Reddy, S.S. 2013. Management of Turcicum leaf blight of maize caused by Exserohilum turcicum in maize. International Journal of Scientific and Research publications. 3 (10): 1-4.

Shivapuri, A., Sharma, O.P. and Jhamaria, S.L. 1997. Fungitoxic properties of plant extracts against pathogenic fungi. Journal of Mycology and Plant Pathology 27: 29- 31.

Singh, A.K., Singh, R.N. and Singh, S.P. 1998. Studies on inhibitory effect of leaf extract of higher plant on Helminthosporium sativum and Alternaria triticina. Plant Protection Progress Report, 1998-99. All India Coordinated Wheat Improvement Project, Directorate of Wheat Research, Karnal, India, pp. 57-58.

Sood, R. and Dohroo, N.P. 2003. Efficacy of botanicals in-vitro against Phyllosticta 
zingiberi causing leaf spot of ginger. Plant Disease Research 18: 174-175.

Ullstrup, A.J. 1970. A comparison of monogenic and polygenic resistance to H. turcicum in corn. Phytopathology 60: 1597-1599.

Verma, S. and Dohroo, N.P. 2003. Evaluation of botanicals in-vitro against Fusarium oxysporum f. sp. pisi causing wilt of pea. Plant Disease Research 18: 131134.

Vincent, J.M. 1927. Distortion of fungal hyphae in the presence of certain inhibitors. Nature 59: 850 (cf: Karnataka Journal of Agricultural Sciences 20(3): 541-544).

\section{How to cite this article:}

Wani, T.A., Mushtaq Ahmad and Anwar, A. 2017. Evaluation of Fungicides, Bioagents and Plant Extracts against Exserohilum turcicum causing Turcicum Leaf Blight of Maize. Int.J.Curr.Microbiol.App.Sci. 6(8): 2754-2762. doi: https://doi.org/10.20546/ijcmas.2017.608.329 